\title{
CULTURAL IDENTITY AND YOUTH (THE CASE OF MUSLIM SOCIETY)
}

\author{
ABDELLAH KEDIR AHMED ${ }^{* *}$
}

\section{Kültürel Kimlik ve Gençlik (İslam Toplumu Örneği)}

Abstract: Preservation of social and personal identity keeps people understand and identify each other more and more. We need youth understand their cultural heritage in order to discover their identity. Among the essential human heritage, history stands corner stone of presenting the beautiful past in order to build best future. Nations share many historical values which help their relationship remain in positive attitude. Reformers mainly use historical relations as best instrument to tackle social and political problems.

* Bu çalışma, 16-18 Mayıs 2014'te Samsun'da yapılan "Gençlik ve Kültürel Mirasımız" adlı uluslararası sempozyumda sunulan bildirinin gözden geçirilmiş ve genişletilmiş biçimidir.

Yrd. Doç. Dr., Alfurkan Univ. College,Ethiopia. Ondokuz Mayıs University, Turkey 
This paper, traces some core points of cultural identity especially of Muslim youth who are in threat of misguiding to a harmful outlook and ideologies, because of the absence of good understanding of their real identity. The significance of Islamic history and its contribution to human civilization are highlighted here together with the role of educational process in cultivating conscious and tolerant generation.

The paper has also focused on common heritage of Muslims to emphasize the importance of peaceful co-existence among them instead of continuous dispute and unrest which is resulting the worst political clashes and devastating what formers had built.

Keywords: Culture, Youth, Cultural identity, Cultural history, Intangible heritage

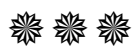

Öz: Bireysel ve sosyal kimliğin korunması, insanları daha iyi anlamaya ve birbirlerini daha iyi tanımalarına imkan sağlar. Bizim gençlerin kimliklerini keşfetmek için onları, kültürel mirasını tanımamız gerekir. İnsanlık mirasının içinde, tarih, daha iyi bir gelecek inşa etmek için şanlı geçmişi koruma görevinin köşe taşını oluşturur. Uluslar, ilişkilerinin olumlu bir şekilde devam etmesine yardımcı olacak pek çok tarihi değerleri paylaşırlar. Reformlar da temel olarak sosyal ve siyasi sorunlarla baş etmek iç in en iyi araç olarak tarihi ilişkileri kullanırlar. Bu makale, gerçek kimliklerinin doğru anlaşılması yoksunluğu çeken, özellikle zararlı bir yola ve ideolojilere kayma tehlikesi içinde olan Müslüman gençliğin tarihi kimliklerinin temel noktalarını ele almaya çalışmaktadır. Burada, İslam tarihinin önemi ve insanlık medeniyetine olan katkısıla birlikte şuurlu ve toleranslı bir neslin ortaya çıkmasındaki eğitim süreçlerinin rolüne vurgu yapılacaktır. Aynı zamanda makale, öncekilerin inşa ettikleri en kötü siyasi çatışmalar ve yıkımlarla sonuçlanan ve süregelen çatışma ve huzursuzluklar yerine, barışçıl birlikteliğin önemini vurgulamak için Müslümanların ortak mirasına vurgu yapacaktır

Anahtar Kelimeler: Kültür, Gençlik, Kültürel Kimlik, Kültürel Tarih, Manevi Miras

\section{畧鳞}

\section{Introduction}

Preservation of cultural identity is a decisive force in a society. It gives individuals a greater sense of shared citizenship ${ }^{1}$. It also enables to answer the questions: what connects people with and distinguishes them

1. C Brown (2001) Understanding International Relations. Hampshire, Palgrave 
from others, what different things can they share to others and what shapes their identity. Cultural identity could be understood by giving possible answers to the above questions.

Young people have to be given the chance to discover and develop their own identity through their interaction with others and educational processes and activities those take place in and out of school. When people from different variety of nations and nationalities and cultures come together, different values and lifestyles clash and raise questions about differences and similarities. By facing those questions and dealing with answers, with careful guidance of teachers, youth has the chance to grow developed social and personal identity. Hince cultural identity and cross-cultural communication amongst diverse groups promotes positive youth development and social cohesion.

Erik Erikson (1902 -1994) in his work on the theory of Psychosocial Development which still stands as one of the best researches in this subject shows that, our Ego identities(sense of self)develops through 53 social interactions2. Erikson's work on identity is therefore of great influence in today's world in which technology is in some aspects, the driving force to identity crises among the youth. In this alarming situation, there is vital need of preserving our cultural identities especially among the youth.

Among the important values to be taught as a heritage, is nation's history. Every nation has its own historical values to be preserved and kept as a heritage. The effective mechanism to do so is educational process which involves historical heritage in its plan, aiming at cultivating mind of young generation with values left by forefathers.

This paper tries to put light on the importance of history in cultural identity and the role of education in empowering cultural identity. The emphasis has been made on historical heritage and its basic knowledge as the core factor of social and cultural identity.

2. Erik H. Erikson Autobiographic Notes on the Identity Crisis Page 730 of 730-759 


\section{I.Personal And Social Identity}

Identity as stated by Stuart Hall, (1990) ${ }^{3}$ is what distinguishes us from others and makes us the same as others. This definition puts a strong emphasis on 'others' suggesting that we cannot know much about our own identity without seeing it in contrast to other people around us. We develop our own identity by comparing ourselves to others. Through this comparison, we learn whom we want to be similar to and whom we want to distance ourselves from. The development of identity can hence be seen to take two roads:

On one side, we look at ourselves in contrast to others and define what makes us unique, where we differ from other individuals, where we are special. This is the personal meaning of identity. On the other side, we are 'social animals' and need to relate ourselves to others and share with groups, opinions and things we have in common. This is the social meaning of identity.

Personal identity consists of all the unique characteristics that a person is. Either he consciously aware of, or knows them unconsciously. It means all the things that distinguish us as an individual from other individuals even though we share some of them with others as human beings. This can be our believes, our adherences to particular outlook our finger prints, our voice, our drawing talent, the way we talk, our behavior, our personal principles and values, the things we like or do not like (desire and hobbies), our physical characteristics etc. Our uniqueness emerges not necessarily from the uniqueness of every single aspect but from the unique combination of all of them together. This individual combination of characteristics forms the basis for our own self-respect and for our own understanding of whom we are.

Social identity means the part of our identity that we shape through identifying with or differentiating from certain social groups. A 'social group' in this regard means people who interact with each other, accept

3. Stuat Hall,(1990) Cultural identity and diaspora p.223 
certain rules as members of the group and share a common identity. It is therefore more than a simple collection of individuals, such as people waiting at a bus stop. The members of a social group mostly share common interests or values. Personal and social identities are not in contradiction; they are interdependent. Individuals together make the collective and the collective has an influence on the individuals.

\section{Importance Of Culture In Identity Formation}

Culture is defined as the "Advanced Development of Human Powers: Development of body, mind and spirit by training and experience". ${ }^{4}$ It is an important factor in shaping identity ${ }^{5}$. Some critics of cultural identity argue that the preservation of cultural identity, being based upon difference, is a decisive force in society, and that cosmopolitanism gives individuals a greater sense of shared citizenship ${ }^{6}$. When considering practical association in international society, states may share an inherent part of their 'make up' that gives common ground and an alternative means of identifying with each other. Nations provide the framework for 55 OMÜiFD culture identities called external cultural reality, which influences the unique internal cultural realities of the individuals within the nation. When looking at cultural diversity, we reflect on topics such as tolerance, living together, how to fight discrimination, racism and ethno phobia...etc. But first, we should all take a step back and challenge ourselves. Intercultural learning helps in looking at the other, the different and the diverse, but we can only really see the other, when we first look at the self. Who am I? What is my identity and personal culture? What do I like or not like? When do I feel good, when do I feel bad? How do I cope with things?. It is essential for people to be aware about themselves in order to share with other cultures and not only nationalities, who are they? But also how can they interact and share.

4. The Exford Adranced Learn's Dictionary p.210

5. Pratt, Nicola (2005). "Identity, Culture and Democratization

6 The Limits of Nationalism by Chaim Gans ISBN 978-0-521-00467-1 ISBN 0521004675 


\section{III.Education And Cultural Identity}

Cultural identity develops through educational process and research; the process of exploration and questioning about one's culture in order to understand the implications of membership in a society. During this stage, a person will begin to question why people hold their culture and compare it to the culture of others. This stage is characterized by growing awareness in social and political activities and a desire to learn more about culture. This can be expressed by asking family members questions about heritage, visiting museums, reading of relevant cultural sources, enrolling in school activities, or attendance at cultural events. Education moreover, stands vital means of understanding cultural diversity.

Methodology of teaching history in general education is most of the time influenced by standing political situations. This phenomenon affects our youth in having good background of history. Because of colonization, so many colonized nations and people lost original sources of their real history. The exploration of historical sources and inculcating it in the curriculum should be the main task of scholars who deal with educational planning particularly history and Historiography. ${ }^{7}$ Historiography should be their basic research methodology to correct the distorted facts, they should have highlight the neglected events and moreover, find methodology that attaches new generation to the past. It is also important in education process bringing culture and history together to achieve the preservation of heritage. Good education combined with cultural identity equips youth with the right attitude, freedom and confidence to face the cultural crisis.

\footnotetext{
7 a- The principles, theory, and history of historical writing

b-The writing of history; especially: the writing of history based on the critical examination of sources, the selection of particulars from the authentic materials, and the synthesis of particulars into a narrative that will stand the test of critical methods(Concise Dictinaryof Oxford.)
} 


\section{IV.Culture And History}

History often combines the approaches of anthropology and history to look at popular cultural traditions and cultural interpretations of historical experience. It examines the records and narrative descriptions of past knowledge, customs, and arts of a group of people. Its subject matter encompasses the continuum of events occurring in succession leading from the past to the present and even into the future pertaining to a culture. Cultural history records and interprets past events involving human beings through the social, cultural, and the arts that a group favors. Jacob Burckhardthelped in founding cultural history as a discipline. He studied and interpreted the record of human societies by denoting the various distinctive ways of living built up by a group of people under consideration ${ }^{8}$. Cultural history involves the aggregate of past cultural activity, such as ceremony, class in practices, and the interaction with locales.

As indicated in the introduction, every nation has its own historical values to be preserved and kept as a heritage through educational process aiming at cultivating mind of young generation with what ancestors left as cultural and historical values.

UNESCO, in its study of (2001), divided cultural heritages in to two broad categories as tangible and intangible heritage. Accordingly, Cultural heritage is the legacy of physical artifacts (tangible) and also (intangible) attributes of a group or society that are inherited from past generations, maintained in the present and bestowed for the benefit of future generations.. ${ }^{9}$

Tangible heritage includes buildings and historic places, monuments, artifacts, etc., which are considered worthy of preservation for the future. These include objects significant to the archaeology, architecture, science or technology of a specific culture. Objects are

8 Jacob Burckhardt:Historian Of Civilization ,Essay originally published in Contemporary Review, November 1997, Vol. 271, Issue 1582, pp. 250-256

9 » Unesco Office in Cairo » Culture (official site) 
important to the study of human history because they provide a concrete basis for ideas, and can validate them. Their preservation demonstrates recognition of the necessity of the past and of the things that tell its story. Preserved objects also validate memories and draw people and give them a literal way of touching the past. Intensive care should be taken of places and things might be damaged by the hands of tourists, the required pre condition must be fulfilled to display them, and other risks of making an object known and available should be in account.

Intangible heritage includes believes, languages, folklore, songs, music, drama, skills, annual festivals, crafts, and the other parts of culture that can be recorded but cannot be touched and interacted with, without a vehicle for the culture. These cultural vehicles are called "Human Treasures. According to the 2003 Convention for the Safeguarding of the Intangible Cultural Heritage, the intangible cultural

58 heritage ( $\mathrm{ICH})$ - or living heritage - is the mainspring of OMüiFD humanity's cultural diversity and its maintenance guarantees continuing creativity.

\section{V.History As A Common Heritage Of Muslim Societies}

We can never deal with culture without history. It enables to know how and where people were together. In this regard, we realize a phenomenon governing human society today. That is classification of our world into two biggest religions, Islam and Christianity; although the general tendency of the majority of western scholars seems to neglect this factor in order not to see the world in this prospect.

According to the CIA's (World Fact book, July 2012), out of almost $7 \mathrm{Bln}$. of world population, $54.7 \%$ is the three great world religions, sharing $23.2 \%$ Muslim and 31.5\% Christian with very less but historically important, Jewish $0.2 \%$. These three religions have common name as 'Ibrahimic Religion'. They have common historical background and common general messages, although their adherences today differ in many fundamental interpretations. 
In a specific level, 1.5 billion Muslims have common specific phenomenon and common specific historical and cultural backgrounds. Our youths should have general knowledge of this fact and aware of what all Muslims at least historically share. However, Islamic History is most of the time taught merely in primary level as a brief life history of the Prophet S.A.W.

The emphasis should be done on some critical points:- First, Islam as all Muslims' identity, must be clearly taught. Islam naturally is not a

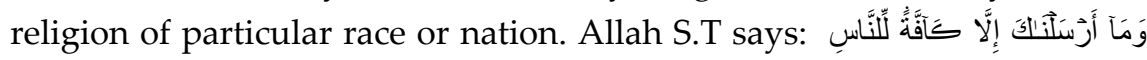

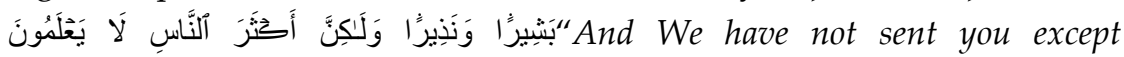
comprehensively to mankind as a bringer of good tidings and a warner. But most of the people do not know". Al-saba: 28.

Socond, Even though the Arabs represent the host and the first society to embrace and promote Islam, the majority of today's Muslims are non-Arab. Among 57 countries which are members of Organization of Islamic Cooperation ${ }^{10}(\mathrm{OIC})$, only 20 are Arabs the rest 37 countries are nonArabs. These 57 countries have many common historical and cultural elements to share and Exchange, the most important is their history.

Third, Both political and cultural history of Muslims is directly related to the cultural identity of Muslims. But most of educational institutions of Muslim countries do not give good attention to this part of their heritage. All of these 57 mentioned countries and other Muslim communities all over the world, refer as their back history to the prophet Muhammad (s.a.w). Hence, 14 century's cultural and political history concerns all of them.

10 Organization of Islamic Cooperation (OIC), an international organization consisting of 57 member states. The organization states that it is "the collective voice of the Muslim world" and works to "safeguard and protect the interests of the Muslim world in the spirit of promoting international peace and harmony". The collapse of the Ottoman Empire and the Caliphate after World War I left a vacuum for a pan-Islamic institution. Losing the Six-Day War in 1967 provided the incentive needed. Leaders of Muslim nations met in Rabat to establish the OIC on 25 September 1969.[official web site of OIC] 
[1]Politically, the seven main consecutive Muslim dynasties passed, hosting and leading the the unified Ummah.They are:

a) 23 years of prophet hood era (610-633), in Madina al- munawwara,

b)30 years of Righteous Khalifs(633-663) in Madinah al- munawwarah,

c)91 years Omayyad dynasty (663-750), based at Damamascus,

d)524 years of Abbasid dynasty (750-1258), based at Baghdad,

e)7 centuries of Andalus kingdom. Beside of Omayyad daynasty, Andlus was conquared and established civilized daynasty between(711-1492)based at gortuba algharnata.c.7 centuries.

f)259 years of Mamluk's dynasty (1258-1517) based at Cairo, \&

g)5 centuries of Ottoman Empire (1517-1923), based at Istanbul.

Which are the direct consecutive successors of power (caliphates).

[2]Culturally, Muslims have rich history of both Religious and scientific heritage.

a) Muslims' traditional and main sources and guides of their belief are the Holy Quran and the prophet's practical teachings of 23 years of his lifetime (sunna). These teachings of Islam continuously developed and transferred in both orally and documentedly. The significant scholars preserved this traditions carefully and transmitted to secceeding generatin.

This heritage belongs to all Muslims, but scarcely have they paid attention to give and grow generations with good knowledge of their common history as Muslims. Rather young Muslim of today is tends to not seing at his historical heritage. Globalization in some aspect has done and still doing a lot to push them toward losing their cultural identity.

b) The youngsters have to remember their great and the glorious heritage by surveying what Islam had contributed to the world's civilization, education, culture and to scientific development. It is worthy to do a brief review of the contribution of Islam to civilization in the following Paragraphs by only mentioning few examplesof History of science in Muslim societies.

$>$ Trigonometry, Sine, Tangent, Co-Tangent were developed by scholar, Muhammad bin Moosaa Al-Khawaarizmi (c. 780 - c. 850) in his 
work known as Hisaab-Al Jab-Wal Muqaabala (The Calculation of Integration and Equation) in the 8th century CE. His work was translated from Arabic into Latin and until the 16th century CE, it was Europe's main textbook on the subject.

Al-Khawaarizmi is considered to be one of the founders of Algebra. The word 'logarithm' or 'Algorizm' is taken from his name or the name of the town Khwaarizm (Kheva), in what is now Uzbekistan, where he was born. The use of zero was adopted by him, that was devised in India some centuries earlier, a numeral of fundamental importance, leading up to the so-called arithmetic of positions and the decimal system. His pioneering work on the system of numerals is well known as "Algorithm," or "Algorizm." In addition to introducing the Arabic numerals, he developed several arithmetical procedures, including operations on fractions. Another great mathematician was the Persian 'Umar ibn Ibrāhīm al-Khayyām Nīshāpūrī (18 May 1048 - 4 December 1131; who offered to the world geometric and algebraic solutions of the second degree. Naseeruddeen wrote the treatise on quadrilateral trigonometry, as well as plain and spherical geometry.

Ibn Haitham,born in $965 \mathrm{CE}$ was the first to explain that all vision was made possible because of refraction of light rays. The work of Ibn Haitham was repeated and expanded upon by Persian Kamal-Uddin Al Farisi (died 1329 CE) who observed the path of rays of light in the interior of a glass sphere in order to examine the refraction of sunlight in rain drips. This led him to an explanation of the genesis of primary and secondary rainbows. ${ }^{11}$

The invention of the pendulum and the presentation of a water clock to Emperor Charlemagne by Haaroon Ar-Rasheed is well known and famous history. The great historian Gibbons wrote in his 'Decline and Fall of the Roman Empire' (Volume 5) that the science of chemistry owes its origin and improvements to the Muslims. In the Science of mechanics

11. (Optometry Today, publication of the Association of Optometrists, England, march 28, 1987), Professor Hirschberg 
Moosaa bin Shaakir namely Abū Ja'far, Muḥammad ibn Mūsā ibn Shākir (before 803 - February 873), described one hundred pieces of mechanical equipment in his book of artifices. Other outstanding Muslim treatises included Al Kitaab Fi Ma'rifat Al-Hiya Al-Handasiyyah (The Book of the Knowledge of Ingenious Geometrical Contrivances) by Abul Fiaz bin Al Raz and Kitaab Meezanal-Hikmah (The Book of Balance and Wisdom) by Al-Khazini. He also did work on accurate weighing, and determination of the specific gravity of substances. Camera Obscura was invented by Ibn Haytham in 1038CE.

$>$ Qaadhi Abu Bakr had developed the theory of relativity in the 8th century CE. in terms of time and space by means of mathematical equations and astrophysics. Imagine, Einstein was not even born in the Western world, who propounded the same theory of relativity much later

62 in the 20th centuryCE.

As far as geography was concerned, Muslim scientists established that the world was round in the 9th century CE, and the first map of the globe was made during the Caliphate of Ma'moon.

> Paper Making was among the earliest skills attained by the Muslims. As early as the 8th century CE, high quality paper was being manufactured in Samarqand. Egypt was known to have its first paper mill in the year $900 \mathrm{CE}$. The earliest Arabic manuscript written on paper that has been discovered is the Ghareeb Al Hadeeth by Abu 'Ubayed, dated $837 \mathrm{CE}$. It can be seen in Holland preserved in the library at the University of Leyden.

Spain was an industrial center and one of the wealthiest and most thickly populated among the European countries under Islamic rule. Muslims were leading in weaving wool, producing silk, pottery, jewelry, leather and perfume industry. In the Middle Ages, world trade was commanded by Muslims and Baghdad Bukhaara and Samarqand remained centers for world fairs until the 16th century CE. The Bayt AlHikmah at Cairocontained two million books, the library at Tripoli 
contained some three million, but this library was burned down by the Christians during the first Crusade.

In the area of Medicine, the necessity of medication included in the original doctrines of the prophet (S.A.W). He urged people to "take medicines for their diseases"12, as people at that time were reluctant to do so. He also said, "God created no illness, except that He has established for it a cure, except for old age."13 Ibn Sina (d. 1037), better known to the West as Avicenna, was perhaps the greatest physician until the modern era. His famous book, Al-Qanun fi al-Tibb, remained a standard textbook even in Europe, for over 700 years. Ibn Sina's work is still studied and built upon in the East. Muslim scholars used human cadavers to study anatomy and physiology and to help their students understand how body functions. This empirical study enabled surgery to develop very quickly.

Al-Razi( Abu Bakr Muhammad ibn Zakariya' al-Razi), born in the Iranian City of Rayy in $865(251 \mathrm{H})$, (d. 932)...is known in the West as Rhazes, the famous physician and scientist. He was one of the greatest physicians in the world in the middle ages. He stressed empirical observation and clinical medicine and was unrivalled as a diagnostician. He also wrote a treatise on hygiene in hospitals.

Abul-Qasim Az-Zahrawi Abu al-Qasim Khalaf ibn al-Abbas AlZahrawi (936-1013), was a very famous surgeon in the eleventh century, known in Europe for his work, Concession or "Kitab al-Tasrif".

These are only few examples from the Muslims heritage to the current world. It reflects the richest and un forgotable share of islamic civilaization to human history.The youngers have to be taught this heritage so that they preserve their identity and contribute further to development and betterment of their societis and human civilization at large.

12 Ibn Abdilbarr, Al-tamhiid 5/584

13 Ahmad bin Hanbal. Al-Musnad 4/278 


\section{Conclusion}

Preservation of social and personal identity keeps people understand and identify each other more and more. We need youth understand their cultural heritage in order to discover their identity. Among the essential human heritage, history stands corner stone of presenting the beautiful past in order to build best future. Nations share many historical values which help their relationship remain in positive attitude. Reformers mainly use historical relations as best instrument to tackle social and political problems.

This paper, traces some core points of cultural identity especially of Muslim youth who are in threat of misguiding to a harmful outlook and ideologies, because of the absence of good understanding of their real identity. The significance of Islamic history and its contribution to human civilization are highlighted here together with the role of educational process in cultivating conscious and tolerant generation.

The paper has also focused on common heritage of Muslims to emphasize the importance of peaceful co existence among them instead of continuous dispute and unrest which is resulting the worst political clashs and devastating what formers had built.

Laslty, I advice the researchers of anthropology to focus on investigating and reasoning out how and why the significant Muslim scholars contribution to the human civilization collapsed or reverse? And what will be the right way of bringing young peouple to be aware of their identity and share their effort for common understanding and readiness to cooperate with cultural heritage preservation

\section{References}

A . Hourani, A History of the Arab Peoples, Faber \& Faber, London, 1991 Ahmad bin Hanbal. Al-Musnad,Baghdad 1968

Al- Bukhari, Al jami Al saheeh, Damascus 1976

B. Brend, Islamic Art, British Museum Press, London, 1991

C Brown Understanding International Relations. Hampshire, (2001)

Erik H. Erikson Autobiographic Notes on the Identity Crisis, 1970 
F .Macdonald, The World of Islam up to the 1500's, Collins Educational, London, 1991

Gad Barzilai, Communities and Law: Politics and Cultures of Legal Identities University of Michigan Press, 2003.

Gutas, Dimitri Greek Thought, Arabic Culture: The Graeco-Arabic Translation Movement in Baghdad and Early 'Abbasaid Society. Routledge. (1998-07-23). p. 133

Hall, S., \& Du Gay, Questions of cultural identity. London: P. (1996). Sage

Holliday, Adrian (May 2010). "Complexity in cultural identity". Language and Intercultural Communication

Ibn Abdilbarr, Al-tamhiid Cairo 1982

J Child, The Rise of Islam, Heinemann, Oxford, 1991

P. Bargley \& H Bourdillon, Medieval Islam, Hodder \& Stoughton, 1993

P. Mantin \& R Mantin, The Islamic World, CUP, Cambridge, 1993

Singh, C. L"New media and cultural identity". China Media Research . (2010). 6 (1): 86.

Stewart, Edward C., \& Bennet, Milton J. American cultural patterns: A cross-cultural perspective (Rev. ed.). Yarmouth, ME: Intercultural Press. (1991).

The Decline and Fall of the Roman Empire, Vol. 1-5 Paperback - January 1, 2004

Tice, Terrence N. "Cultural Identity", The Education Digest, May 1999

\section{橉}


